\title{
Superficial Incision
}

National Cancer Institute

\section{Source}

National Cancer Institute. Superficial Incision. NCI Thesaurus. Code C112020.

An incision that involves only the skin or subcutaneous tissue. 